\title{
ANALISIS PENGARUH TINGKAT RELIGIOSITAS TERHADAP KINERJA KARYAWAN BANK SYARIAH (STUDI KASUS PADA KARYAWAN KANTOR PUSAT BANK SYARIAH X)
}

\author{
Eva Nuroniah $^{1}$ dan Abdi Triyanto ${ }^{2}$
}

\begin{abstract}
1.Program Studi Perbankan Syariah, Sekolah Tinggi Ekonomi Islam SEBI, Email: evanuroniah@gmail.com

2Program Studi Perbankan Syariah, Sekolah Tinggi Ekonomi Islam SEBI, Depok, Jawa Barat. Email:abdi.triyanto@yahoo.co.id
\end{abstract}

\begin{abstract}
ABSTRAK: Tujuan dari penelitian ini adalah untuk mengetahui tingkat religiositas dan kinerja karyawa bank syariah $\mathrm{x}$; pengaruh religiositas karyawan erhadap kierjanya. Lebih lanjut penelitian ini juga melihat bagaiamana manajer meningkatkan kinerja karyawan. Objek dari penelitian ini adalah karyawan bank syariah $\mathrm{X}$ yang ada dikantor pusat. Metodologi penelitian ini menggunakan kombinasi kualitaif dan kuantitaif. Data yang digunakan adalah data primer dari wawancara dan juga data sekunder. Dalam menganalisis data kuantitatif menggunakan regression test, sedangkan untuk yang kualitatif menggunakan induktif. Hasil dari penelitian ini adalah; tingkat religiositas bank syariah $\mathrm{X}$ berada pada level yang bagus dan juga tingkat kinerja karyawan; tingkat religiositas berpengaruh sebesar 33,8 \% terhadap kinerja karyawan dan selebihnya dipengaruhi oleh factor yang lain.
\end{abstract}

Kata kunci: Religiositas, kinerja karyawan, Bank syariah, dan Regresi.

ABSTRACT: The purpose of this research is to test : (1) how the religiosity rate and workers performance in $x$ syariah bank; (2) the influence of religiosity rate to workers performance. furthermore, this research will looking for the way how to increase workers performance. The object of this research is the workers of $x$ syariah bank at the head office. The method of this research is the combination between quantitative and qualitative method. Using two types of data, the primer data (questionnaire, interview and observation) and the secondary data (documentation and literature). In quantitative analysis Regression test is used. Whereas for qualitative analysis, using inductive method. The result of this study show that: (1) the religiosity rate of $x$ syariah bank workers is relatively at very religious level, Workers performance rate also relatively at very good level; (2) that there is a significant influence $33,8 \%$ between religiosity rate to performance. Whereas $66,2 \%$ performance influenced by other aspect such as culture and job environment, leadership from top management, job motivation, job satisfaction, and others.

Keywords: Religiosity, performance, Islamic bank, Regression 
86 | Nuroniah \& Triyanto: Analisis Pengaruh Tingkat Religiositas terhadap Kinerja Karyawan Bank syariah...

\section{PENDAHULUAN}

Sepanjang tahun 2012 industri perbankan syariah di Indonesia tumbuh cukup moderat. Hal ini ditunjukkan dengan meningkatnya aset perbankan syariah yang menembus angka Rp. 174,09 triliun atau tumbuh 37 persen year on year (yoy) dengan pangsa pasar menyentuh level 4,3 persen. Untuk pembiayaan dan penghimpunan masingmasing sebesar Rp. 135,58 triliun (tumbuh 40,06 persen yoy) dan Rp. 134,45 triliun (32,06 persen yoy). serta ditunjukkan dengan adanya 11 bank umum syariah, 24 unit usaha syariah, serta 156 bank perkreditan rakyat syariah. (Perbankan Syariah Dituntut Kembangkan Sektor Produktif, Okt 2012).

\section{Tabel 1.1 Perkembangan Bank syariah}

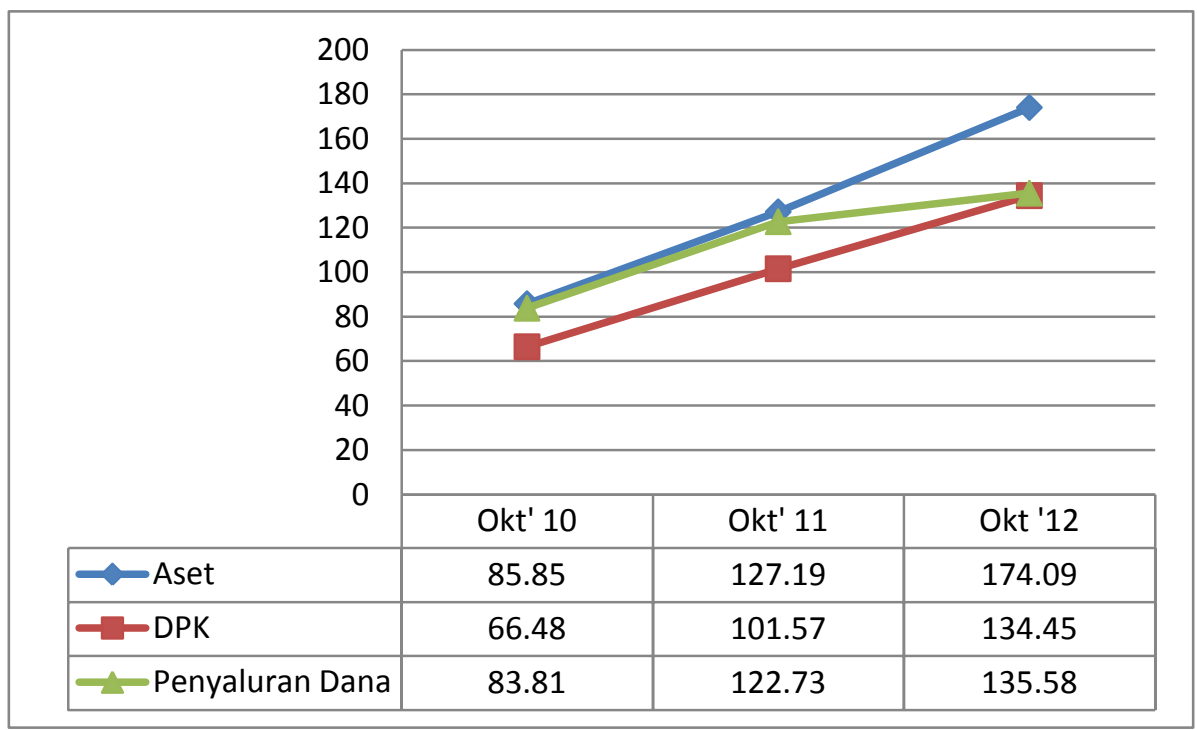

Salah satu tantangan terbesar perbankan syariah saat ini adalah keterbatasan sumber daya manusia, baik dari segi kualitas maupun kuantitas. Sehingga untuk mengatasi hal ini diperlukan pengembangan SDM bank syariah. Selanjutnya akan turut serta untuk meningkatkan nilai kompetitif bank syariah itu sendiri. Karena dalam perspektif manajemen modern, human capital merupakan elemen terpenting dan penentu dalam mencapai visi dan keunggulan bersaing sebuah organisasi. (Setiawan, 2010).

Ismail (2010) mengemukakan bahwa, "Sumber daya manusia dalam suatu perusahaan memegang peranan yang sangat penting dalam melaksanakan aktifitas perusahaan guna mencapai tujuan perusahaan". Perusahaan harus mampu menciptakan usaha-usaha agar sumber daya manusia yang dimilikinya dapat memberikan kontribusi yang baik bagi perusahaan. Begitu juga menurut Asnaini (2008) menyatakan bahwa "SDM Perbankan Syariah harus memiliki pengetahuan dan pemahaman di bidang bisnis, memahami implementasi prinsip-prinsip bisnis Islam dan konsisten dalam bekerja. serta Imtek (Ilmu \& Teknologi) dan Imtaq (Iman dan Taqwa) harus seimbang". 
Jurnal Ekonomi dan Perbankan Syariah

Vol. 3. No.1, April 2015: 85-98, ISSN (cet): 2355-1755

Menurut Amin, seperti yang dikutip Kertajaya \& Sula (2006) bahwa "karyawan berkreasi berdasarkan "prinsip-prinsip langit" (celestial principle)." Karyawan tidak hanya dituntut menyelanggarakan prinsip pengelolaan usaha yang sehat yang dikenal dengan Good Corporate Governance dengan transparansi dan akuntabiliats yang tinggi. Mereka bekerja tidak semata-mata karena alasan finansial, tetapi termotivasi pengabdian kepada Sang Maha Kuasa. Mempersembahkan kinerja terbaik bagi perusahaan menjadi kunci untuk memasuki keabadian menuju-Nya.

Spiritual behaviour (religiositas) adalah bentuk perilaku karyawan yang dijiwai nilai-nilai spiritual keagaamaan (religi) dalam segala bentuk pekerjaan dan tugasnya. Sehingga pada suatu tingkat ketika semua stakeholder utama dalam bisnis, khususnya bisnis perbankan syariah seperti nasabah, karyawan dan pemegang saham memperoleh kebahagiaan. Lebih dari itu, bagi seorang Muslim, Religiositas dalam bekerja mengandung nilai-nilai ibadah dan diyakini akan mendapatkan ganjaran/pahala dari Allah SWT di akhirat kelak.

Bank syariah x saat ini merupakan bank syariah terdepan di Indonesia. Hal ini dapat dilihat dari jumlah asset, kantor-kantor cabang serta jumlah SDM-nya yang menduduki peringkat pertama dibandingkan dengan bank syariah lainnya. Hal ini sesuai dengan yang diungkapkan oleh Fauzi (2012, hal. 103) bahwa "Bank syariah dirancang dan dibangun bersama untuk menjadi pioneer bagi pembangunan Indonesia yang lebih baik, serta untuk mengusung peradaban berbasis religiositas masa depan". Bahkan Fauzi (2012, hal. 105)juga menekankan untuk menjadikan "Bank syariah sebagai Masjid Sosial dan Sajadah Panjang para SDM-nya". Hal ini menunjukkan ajakan bagi para karyawan bank syariah untuk melandasi pekerjaannya sebagai jihad dan dakwah untuk Islam.

Pada bank syariah terdapat perbedaan mendasar tentang adanya SDM yang Islami. yakni dalam segala kegiatan para karyawannya dilakukan berdasarkan prinsip-prinsip ibadah kepada Allah. Serta meyakini bahwa bekerja adalah merupakan salah satu bentuk ibadah. Guna mencapai keuntungan duniawi dan ukhrowi. Hingga pada akhirnya, landasan filosofi religiositas ini sebagai salah satu cara memajukan dan meningkatkan nilai perusahaan.

Penelitian tentang religiositas pernah dilakukan oleh Homisah (2009), Rusdi (2009) dan Azmi (2010). Terdapat hubungan yang signifikan antara religiositas dengan konsep diri mahasiswa psikologi UIN (Homisah, 2009). Pengaruh religiositas yang signifikan terhadap forgiveness pada mahasiswa STID Al-Hikmah Jakarta (Rusdi, 2009). Obyek penelitian keduanya adalah mahasiswa. Sedangkan peneliti belum menemukan penelitiann religiositas terhadap kinerja karyawan sebuah perusahaan. Apalagi jika perusahaan tersebut adalah perusahaan yang beroperasi dan mempunyai filosofi keIslaman (syariah) yang kental. Hanya penelitian Azmi (2010) yang menggunakan karyawan sebagai obyek. Yakni adanya hubungan positif yang signifikan antara relgiositas dengan komitmen pada organisasi pegawai PT. Elnusa divisi Geosains.

Berdasarkan uraian di atas dan karakteristik Islami yang harus sejalan dengan bank syariah, baik SDM maupun aktifitas operasional dan manajemennya, serta nilai-nilai Islami yang diterapkan bank syariah. peneliti ingin menguji pengaruh antara variabel independen tingkat religiositas terhadap variabel dependen kinerja karyawan. Peneliti merumuskan masalah penelitian dalam beberapa pertanyaan penelitian berikut ini: 
88 | Nuroniah \& Triyanto: Analisis Pengaruh Tingkat Religiositas terhadap Kinerja Karyawan Bank syariah...

Bagaimana tingkat religiositas para karyawan Bank Syariah X?; Bagaimana kinerja para karyawan Bank Syariah X?; Apakah tingkat religiositas terdapat pengaruh terhadap kinerja karyawan Bank Syariah X?.

\section{TELAAH PUSTAKA}

\section{Pengertian Kinerja dan Penilaian Kinerja}

Kinerja adalah hasil atau tingkat keberhasilan seseorang secara keseluruhan selama periode tertentu didalam melaksanakan tugas dibandingkan dengan berbagai kemungkinan, seperti standar hasil kerja, target atau sasaran atau kriteria yang telah ditentukan terlebih dahulu dan telah disepakati bersama. (Rivai, 2008, p. 14)

Menurut Robbin(1996) Perolehan tujuan yang telah ditetapkan merupakan salah satu tolak ukur kinerja individu. Ada tiga kriteria dalam melakukan penilaian kinerja individu, yakni:

(a) tugas individu; kemampuan menyelesaikan pekerjaan berdasarkan tugas dan tanggung jawab masing-masing individu

(b) perilaku individu; perilaku keseharian seorang individu dalam lingkungan kerja, dan

(c) ciri individu, yakni kemampuan khusus yang menonjol dari seorang individu tersebut.

Dengan demikian, kinerja adalah kesediaan seseorang atau kelompok orang untuk melakukan sesuatu kegiatan dan menyempurnakannya sesuai dengan tanggung jawabnya dengan hasil seperti yang diharapkan. Jika dikaitkan dengan performance sebagai kata benda (noun) dimana salah satu entrinya adalah hasil dari sesuatu pekerjaan (things done), pengertian performance atau kinerja adalah hasil kerja yang dapat dicapai oleh seseorang atau kelompok orang dalam suatu perusahaan sesuai dengan wewenang dan tanggung jawab masing-masing dalam upaya Perolehan tujuan perusahaan secara legal, tidak melanggar hukum dan tidak bertentangan dengan moral atau etika.

\section{Unsur-unsur dalam Penilaian Kinerja}

Menurut (Rivai, 2008, p. 24)ada beberapa unsur-unsur kunci yang harus ada dalam Penilaian Kinerja, diantaranya adalah Pendefinisian misi, penetapan tujuan dan sasaran-sasaran perusahaan, Penetapan rencana strategis dan kebijakan operasional perusahaan, Penetapan dan pengembangan indikator-indikator kinerja, serta Pengukuran kinerja dan penilaian hasil pengukuran.

Indikator kinerja merupakan sesuatu yang akan dihitung dan diukur. Penetapan indikator hendaknya didasarkan pada perkiraan yang realistis dengan memperhatikan tujuan, sasaran dan hasil yang diinginkan. Perlunya pertimbangan antara sistem ukuran kinerja dengan kondisi nyata yang dihadapi. 
Dibawah ini adalah gambar pola penetapan indikator kinerja menurut (Rivai, 2008, p. 28).

Gambar 2.1 Pola Penetapan Indikator Kinerja

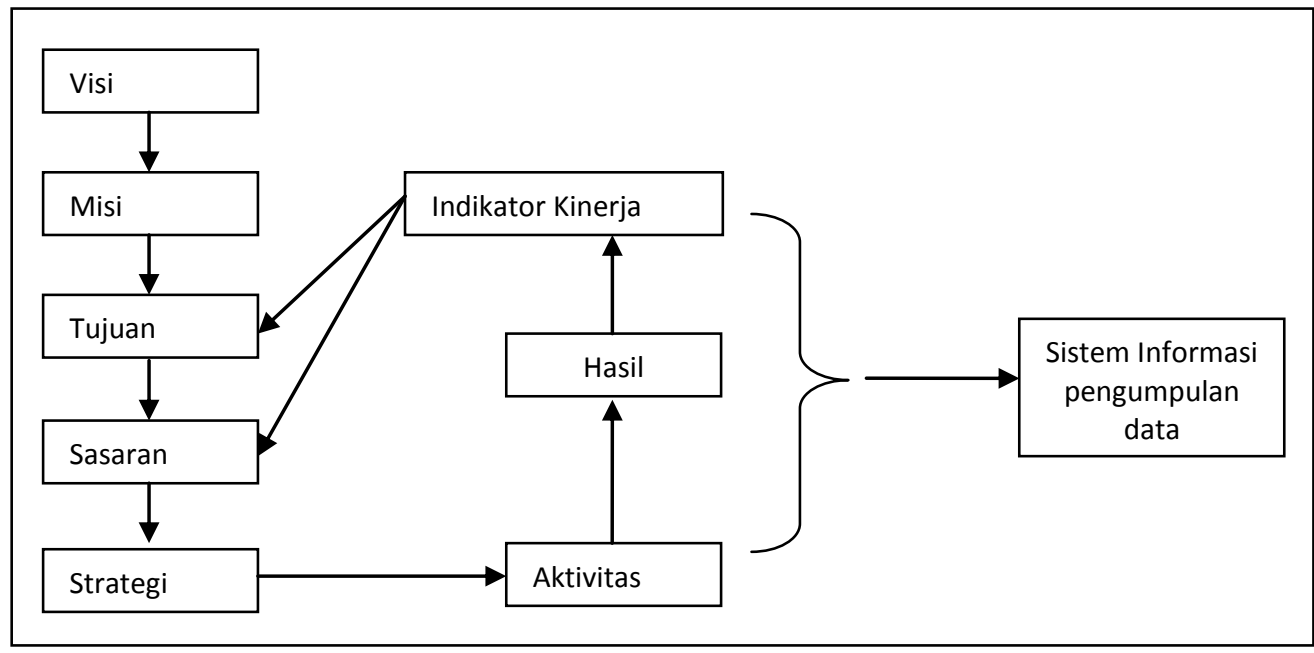

Dari gambar di atas dijelaskan bahwa indikator kinerja harus mencakup tujuan dan sasaran perusahaan. Dari pelaksanaan strategi perusahaan diperlukan penilaian atas hasil yang dicapai. Hasil tersebut yang merupakan unsure utama dalam indicator kinerja. Sehingga dari kumpulan penilaian indicator kinerja akan dimasukkan kedalam sistem informasi pengumpulan data perusahaan. Selanjutnya akan menjadi dokumen legal perusahaan.

\section{Tujuan Penilaian Kinerja}

Menurut Gomez-Meijia (1998) terdapat banyak cara bagi perusahaan untuk mengupayakan agar kinerja organisasi meningkat. Misalkan dengan mengadakan pelatihan, pengembangan serta penilaian kinerja kepada para karyawannya. Sistem penilaian kinerja akan bekerja dengan baik ketika tujuan formal perusahaan menggunakan penilaian kinerja konsisten terhadap tujuan penilaian, termasuk penilai dan yang dinilai. Secara umum menurut (Rivai, 2008, p. 50), hlm. 50), penilaian kinerja bertujuan untuk meningkatkan kinerja karyawan, menetapkan tujuan perusahaan, mengidentifikasi pelatihan dan pengembangan yang dibutuhkan, perencanaan sumber daya manusia.

\section{Metode Penilaian Kinerja}

Menurut Soeprihanto (2001) mengajukan metode sistem rating, sistem peringkat, penilaian berdasarkan tujuan dan standar. Lain halnya dengan Gasperz (2005), ia membagi penilaian berdasarkan outcome kinerja dan pengendalian kinerja. Namun secara umum soeprihanto (2001) membagi penilaian ke dalam penilaian objektif dan subjektif.

1. Metode Penilaian Sujektif

2. Metode Penilaian Objektif

3. Metode Penilaian Kinerja Yang Berorientasi Masa Lalu 
90 | Nuroniah \& Triyanto: Analisis Pengaruh Tingkat Religiositas terhadap Kinerja Karyawan Bank syariah...

4. Metode Penilaian Kinerja Yang Berorientasi Masa Depan

\section{Indikator-indikator Penilaian Kinerja Karyawan}

Indikator-indikator yang digunakan untuk menilai kinerja karyawan menurut (Rivai, 2008, p. 616) antara lain: Produktivitas kerja karyawan, Pengamalan target budaya kerja dan Karakteristik potensi diri. Indikator selanjutnya adalah nilai hasil pekerjaan yang telah diselesaikan. Meliputi: Kerajinan (kehadiran dalam pekerjaan), Kuantitas dan kecepatan menyelesaikan pekerjaan, Ketelitian/keakuratan, Loyalitas, Inisiatif, Kerjasama, Kepemimpinan dan Kemampuan menghargai karya bawahan.

\section{Pengertian Religiositas}

Religi berasal dari bahasa latin yang berarti mengumpulkan/membaca, dan religare yang berarti mengikat. Artinya, agama merupakan kumpulan cara-cara mengabdi kepada tuhan dan sifatnya mengikat bagi manusia, yaitu ikatan antara roh manusia dengan tuhan demikianlah yang disampaikan Nasution (1985) dalam Homisah (2009). Menurut Bafadal (Bafadal, 2005, p. vii), religi (agama) dalam terminologi Islam dikatakan sebagai Wad'un ilahiyyyun yusaqqu li zawil 'uqul li sa'adatihim dun-yan wa ukhra; yang artinya "Aturan Tuhan yang diarahkan untuk pembimbingan makhluk berakal (manusia) bagi kebahagiaan hidup di dunia dan di akhirat". Agama menjadi penting bagi setiap individu karena peraturan dan ajaran agama akan mengarahkan pengamalan dan tindakan dalam kehidupan manusia dalam kesehariannya.

Menurut Darajat (1996, p. 3) membagi jiwa keberagaaman menjadi dua istilah. Yakni kesadaran beragama (religious counsciousness) adalah aspek mental dari aktivitas agama. Aspek ini merupakan bagian/segi agama yang hadir (terasa) dalam pikiran dan dapat diuji melalui introspeksi. Sedangkan yang kedua adalah pengalaman agama (religious experience) adalah unsur perasaan dalam kesadaran agama, yaitu perasaan yang membawa kepada keyakinan yang dihasilkan dalam tindakan (amaliyah) nyata.

Jadi yang dimaksud religiositas adalah sistem simbol, sistem keyakinan, sistem nilai dan sistem perilaku seorang manusia yang berdasarkan aturan Tuhan (Allah) yang diarahkan untuk membimbing manusia agar memenuhi kebahagiaan hidup di dunia dan di akhirat. Religiositas ini sangat penting. Karena hanya dengan religiositaslah manusia mampu mengerti hikmah dan makna kehidupan sebenarnya. Serta sudah sunnatullah pula bahwa manusia (dengan diberi fitrah keberagamaan) sangat membutuhkan tuhan (Allah).

\section{Perspektif Islam tentang Religiositas}

Islam menyuruh umatnya untuk beragama (atau berislam) secara menyeluruh (kaaffah) . Seperti firman Allah dalam QS. Al-Baqarah ayat 208 yang artinya: "Hai orangorang yang beriman, masuklah kamu ke dalam Islam secara keseluruhan, dan janganlah kamu turut langkah-langkah syaitan. Sesungguhnya syaitan itu musuh yang nyata bagimu”. (QS. Al-Baqarah:208)

\section{Dimensi-Dimensi Religiositas}

Seperti telah dikemukakan sebelumnya bahwa religiositas dapat diwujudkan dalam berbagai sisi kehidupan manusia. Aktivitas beragama tidak hanya ditunjukkan ketika seseorang mealakukan ritual (beribadah) saja, namun juga melakukan aktivitas lain yang didorong oleh kekuatan supranatural. Karena itu keberagamaan seseorang 
Jurnal Ekonomi dan Perbankan Syariah

Vol. 3. No.1, April 2015: 85-98, ISSN (cet): 2355-1755

meliputi berbagai macam sisi atau dimensi. Glock dan Stark (Robertson, 1995, p. 295)

menjelaskan religiositas menjadi lima dimensi Yaitu: Dimensi idiologi (keyakinan), Dimensi praktek agama, Dimensi pengamalan dan konsekuensi, Dimensi pengetahuan agama (intelektual), Dan Dimensi pengalaman (penghayatan).

\section{Dimensi-dimensi dalam Religiositas Islam}

Menurut Ancok \& Suroso (1995), rumusan Glock \& Stark yang membagi keberagamaan menjadi lima dimensi dalam tingkat tertetntu mempunyai kesesuaian dengan Islam. Walaupun tak sepenuhnya sama, dimensi keyakinan dapat disejajarkan dengan aqidah, dimensi praktik agama disejajarkan dengan syariah dan dimensi pengamalan disejajarkan dengan akhlak. Dimensi-dimensi terseut adalah Dimensi Keyakinan atau Aqidah, Dimensi Peribadatan atau Praktek Agama atau Ibadah, Dimensi Pengetahuan atau Ilmu, Dimensi Pengalaman atau Penghayatan atau Ruhiyah Islam dan Dimensi Pengamalan atau Akhlak (Adab, Akhlak dan Amal).

\section{METODE PENELITIAN}

\section{Pendekatan dan Metode Penelitian}

Metode penelitian pada dasarnya merupakan cara ilmiah untuk mendapatkan data dengan tujuan dan kegunaan tertentu (Sugiyono, 2012, p. 2). Penelitian ini menggunakan pendekatan kuantitatif yang ditunjang dengan kualitatif. Pendekatan kuantitatif digunakan untuk menjelaskan intensitas pengamalan agama dan sikap beragama di kalangan para karyawan, dan faktor-faktor yang mempengaruhinya (Sugiyono, 2012).

Pendekatan kualitatif sebag ai pelengkap analisis. Adapun metode kualitatif yang digunakan adalah analisis induktif. Dengan tujuan antara lain, untuk memberikan deskripsi tentang lokasi penelitian, kinerja para karyawan, dan menjelaskan faktor-faktor yang mempengaruhi kualitas pengamalan agama (religiositas) dan sikap beragama yang ditunjukkan oleh para karyawan Bank Syariah X, diluar variabel-variabel yang telah disebutkan.

Metode penelitian yang digunakan adalah asosiatif, yakni mencari hubungan antara dua atau lebih variabel (Sugiyono, 2012, p. 36). Dalam penelitian ini, peneliti berusaha mencari hubungan antara satu variabel (variabel bebas) dengan variabel terikat. Variabel bebas penelitian ini adalah tingkat religiositas, sedangkan variabel terikatnya berupa kinerja karyawan. Berikut ini akan disampaikan mengenai varibel penelitian.

\section{Populasi dan Teknik Pengambilan Sampel}

Populasi penelitian ini adalah seluruh karyawan bank syariah x yang bertugas/bekerja di kantor pusat yang berjumlah 1.315 orang per September 2012. Sedangkan Teknik pengambilan sampel yang digunakan adalah menggunakan probability sampling yaitu pengambilan sampel secara random atau acak. Adapun metode pengambilan sampel yang digunakan oleh peneliti adalah dengan menggunakan metode random sampling.

\section{Teknik Pengumpulan Data}

Teknik pengumpulan data pada penelitian ini adalah dari data primer dan sekunder. Data primer diambil melalui wawancara terhadap pihak yang terkait penilaian kinerja dan pengembangan karyawan. Serta dilengkapi pula dengan kuesioner yang disebarkan kepada responden yang dijadikan sampel, sebagai perwakilan dari populasi yang ada. Kemudian data sekunder diambil dari dokumentasi perusahaan dan studi kepustakaan. 
92 | Nuroniah \& Triyanto: Analisis Pengaruh Tingkat Religiositas terhadap Kinerja Karyawan Bank syariah...

\section{HASIL DAN ANALISIS}

\section{Distribusi Skoring Berdasarkan Indikator Skala Tingkat Religiositas}

Didalam variabel tingkat religiositas terdapat lima indikator utama, yang merujuk pada dimensi religiositas Glock \& Stark (1965), serta diperjelas oleh Suroso \& Ancok (1995). Yakni berupa Aqidah (keyakinan), Ibadah (praktek agama), akhlak (pengamalan), ilmu (pengetahuan) dan ruhiyah Islam (penghayatan).

Tabel 4.2 Distribusi Scoring Skala Tingkat Religiositas

\begin{tabular}{|c|c|c|}
\hline Kelas Interval & Frekuensi Responden & Kategori \\
\hline $64.29-76.28$ & 41 & Cukup Baik \\
\hline $76.29-88.28$ & 40 & Baik \\
\hline $88.29-100.00$ & 26 & Sangat Baik \\
\hline
\end{tabular}

Dari data tersebut dapat terlihat bahwa 26 orang responden masuk dalam kategori kinerja Sangat Baik. 40 orang masuk pada kategori kinerja yang Baik. Sedangkan 41 orang sisanya masuk pada kategori Cukup Baik. Sehingga dapat disimpulkan bahwa kinerja karyawan termasuk sangat baik. Karena tidak responden yang mendapat nilai rendah (yakni dengan nilai dibawah 60).

\section{Uji Validitas dan Uji Reliabilitas}

Pengujian ini dilakukan dengan menggunakan Pearson Correlation. Pernyatan yang dikatakan valid adalah pernyataan yang memiliki nilai $r$ hitung lebih besar dari $r$ table $(r$ hitung $>r$ table). Nilai $r$ hitung diperoleh dari hasil perhitungan uji validitas dengan menggunakan cara manual dalam Ms. Excel maupun dengan perangkat SPSS versi 18.0. sedangkan untuk $r$ table diperoleh dari table $r$ Product-Moment (two-tailed test) dengan $n$ 107 yaitu 0.190 untuk taraf signifikansi 0.05 ( 5 persen).

Dari hasil uji validitas diatas ditemukan bahwa untuk skala religiositas dan skala kinerja karyawan dinyatakan valid. Dengan $r$ hitung tertinggi yaitu 0,848 dan $r$ hitung terendagh adalah 0.4155 .

Tabel 4.4 Hasil Uji Reliabilitas Skala Religiositas

\begin{tabular}{|c|c|c|}
\hline $\begin{array}{c}\text { Cronbach's } \\
\text { Alpha }\end{array}$ & $\begin{array}{c}\text { Cronbach's } \\
\text { Alpha Based on } \\
\text { Standardized } \\
\text { Items }\end{array}$ & N of Items \\
\hline .745 & .953 & 51 \\
\hline
\end{tabular}

Sumber: diolah

Dari tabel diatas dapat diketahui bahwa koefisien reliabilitas Cronbach's alpha untuk skala tingkat religiositas adalah 0,745. Sedangkan tabel dibawah ini adalah hasil pengujian reliabilitas skala kinerja karyawan. 
Jurnal Ekonomi dan Perbankan Syariah

Vol. 3. No.1, April 2015: 85-98, ISSN (cet): 2355-1755

Tabel 4.5 Hasil Uji Reliabilitas Skala Kinerja Karyawan

\begin{tabular}{|c|c|c|}
\hline $\begin{array}{c}\text { Cronbach's } \\
\text { Alpha }\end{array}$ & $\begin{array}{c}\text { Cronbach's } \\
\text { Alpha Based on } \\
\text { Standardized } \\
\text { Items }\end{array}$ & N of Items \\
\hline .757 & .976 & 36 \\
\hline
\end{tabular}

Sumber: diolah

Dari tabel di atas menunjukkan bahwa, koefisien reliabilitas yang didapat oleh skala kinerja adalah 0,757. Sedikit lebih tinggi dibandingkan koefisien reliabilitas yang diperoleh skala tingkat religiositas.

Dibawah ini dalah tabel rangkuman mengenai hasil pengujian reliabilitas pada penelitian ini.

Tabel 4.6 Koefisien Reliabilitas Instrumen Penelitian

\begin{tabular}{|l|c|c|}
\hline \multicolumn{1}{|c|}{ Instrumen } & Koefisien alpha cronbach & Keterangan \\
\hline Skala religiositas & 0.745 & Reliabel \\
\hline Skala kinerja & 0.757 & Reliabel \\
\hline
\end{tabular}

Dari kedua hasil pengujian reliabilitas di atas menunjukkan bahwa kuesioner yang digunakan pada penelitian ini adalah reliabel atau handal. Hal ini berarti bahwa kedua kuesioner tersebut reliabel/handal digunakan untuk mengukur objek penelitian. Karena dari hasil tersebut menunjukkan bahwa, rangkaian kuesioner tidak memiliki suatu kecenderungan tertentu.

\section{Pengujian Hipotesis Penelitian}

Uji Spearman-Brown

Tabel 4.7 Hasil Uji Korelasi

\begin{tabular}{|lll|c|c|}
\hline & & Religios & \\
\hline Spearman's rho & Religiositas & Correlation Coefficient & 1.000 & $.584^{* *}$ \\
& & Sig. (2-tailed) &. & .000 \\
& & $\mathrm{~N}$ & 107 & 107 \\
\cline { 2 - 5 } & Kinerja & Correlation Coefficient & $.584^{* *}$ & 1.000 \\
& & Sig. (2-tailed) & .000 &. \\
& $\mathrm{~N}$ & 107 & 107 \\
\hline
\end{tabular}

**. Correlation is significant at the 0.01 level (2-tailed).

Sumber: hasil pengolahan data primer dengan program SPSS 18.0

Dari hasil uji korelasi diatas, terlihat bahwa nilai signifikansi adalah sebesar 0,000. Jadi, nilai signifikansi 0,000 jauh lebih kecil dari taraf signifikansi yang ditetapkan yakni 
94 | Nuroniah \& Triyanto: Analisis Pengaruh Tingkat Religiositas terhadap Kinerja Karyawan Bank syariah...

0,05. Sehingga dapat disimpulkan bahwa tingkat religiositas mempunyai pengaruh terhadap kinerja karyawan.

\section{Uji Koefisien Determinasi (Uji $\left.R^{2}\right)$}

Tabel 4.8 Uji Koefisien Determinasi (Uji R2)

\begin{tabular}{|l|l|l|l|l|l|}
\hline Model & & R & R Square & $\begin{array}{l}\text { Adjusted } \\
\text { Square }\end{array}$ & $\begin{array}{r}\text { Std. Error } \\
\text { of the Estimate }\end{array}$ \\
\hline dimension01 & $.581^{\mathrm{a}}$ & .338 & .331 & .30528 \\
& & & & \\
\hline
\end{tabular}

a. Predictors: (Constant), Religiositas

b. Dependent Variable: Kinerja

Sumber: hasil pengolahan data primer dengan program SPSS 18.0

Berdasarkan tabel di atas dapat dilihat bahwa nilai koefisien determinasi $\left(\mathrm{R}^{2}\right)$ sebesar 0.338. hal ini berarti bahwa 33.8\% variabel dependen Kinerja dapat dijelaskan atau dipengaruhi oleh variabel independen tingkat religiositas. Sedangkan sisanya $66.2 \%$ dijelaskan atau dipengaruhi oleh variabel lain diluar penelitian ini. Seperti kepuasan kerja, motivasi kerja, kompensasi dan sebagainya.

\section{Uji Regresi secara Simultan}

Tabel 4.9 Uji Regresi Simultan (Uji F)

ANOVA $^{b}$

\begin{tabular}{|l|c|c|c|c|c|}
\hline Model & Sum of Squares & Df & Mean Square & F & Sig. \\
\hline Regression & 4.990 & 1 & 4.990 & 53.544 & $.000^{\mathrm{a}}$ \\
Residual & 9.786 & 105 & .093 & & \\
Total & 14.776 & 106 & & & \\
\hline
\end{tabular}

a. Predictors: (Constant), Religiositas

b. Dependent Variable: Kinerja

Sumber: hasil pengolahan data primer dengan program SPSS 18.0

Dari hasil diatas dapat diartikan bahwa variabel independen memiliki pengaruh yang signifikan terhadap variabel dependen. Maka dapat disimpulkan bahwa variabel tingkat religiositas dapat dipakai untuk memprediksi variabel kinerja karyawan.

\section{Uji Regresi}

Hasil dari uji regresi dapat dilihat pada table berikut:

Tabel 4.10 Uji Koefisien Regresi

\begin{tabular}{|c|c|c|c|c|c|}
\hline \multirow[t]{2}{*}{ Model } & \multicolumn{2}{|c|}{ Unstandardized Coefficients } & $\begin{array}{c}\text { Standardized } \\
\text { Coefficients }\end{array}$ & \multirow[b]{2}{*}{$\mathrm{T}$} & \multirow[b]{2}{*}{ Sig. } \\
\hline & $\mathrm{B}$ & Std. Error & Beta & & \\
\hline
\end{tabular}


Jurnal Ekonomi dan Perbankan Syariah

Vol. 3. No.1, April 2015: 85-98, ISSN (cet): 2355-1755

\begin{tabular}{|c|c|c|c|c|c|}
\hline (Constant) & .815 & .337 & & 2.416 & .017 \\
Religiositas & .699 & .095 & .581 & 7.317 & .000 \\
\hline
\end{tabular}

a. Dependent Variable: Kinerja

Hasil pengujian variabel independen tingkat religiositas yang dilakukan dengan uji regresi pada tabel di atas menunjukkan bahwa variabel tingkat religiositas memperoleh nilai koefisien regresi sebesar positif (+) 0,699 dan signifikansi 0,000. Hal ini berarti bahwa variabel tingkat religiositas secara positif mempengaruhi kinerja karyawan secara signifikan.

Sehingga, jika semakin tinggi tingkat religiositas maka kinerja karyawan juga semakin tinggi. Demikian juga sebaliknya, jika tingkat religiositas karyawan semakin rendah maka kinerjanya pun akan semakin rendah. Bisa juga dicontohkan dengan, jika tingkat religiositas naik sebesar 1 , maka kinerja akan terpengaruhi sebesar 0,95. (lihat kolom Std. Error dengan nilai 0,95).

Hasil ini sama dengan Hasil penelitian Azmi (2010) yang menunjukkan terdapat hubungan positif yang signifikan antara religiositas dengan komitmen pada organisasi pegawai PT. Elnusa divisi Geosains. Dengan arah hubungan adalah positif, yang berarti semakin tinggi religiositas seseorang, maka semakin tinggi pula komitmen pada organisasinya. Aspek-aspek religiositas memberikan sumbangan perubahan sebesar $37.8 \%$ terhadap variabel komitmen pada organisasi.

\section{Analisis Hasil Penelitian}

\section{a. Motivasi Karyawan}

Salah satu bentuk motivasi yang diberikan perusahaan adalah dengan adanya sistem reward yang berbeda dibandingkan perusahaan lain yang sejenis. Sistem reward pada bank syariah ini tidak hanya diberikan satu kali di akhir periode saja melainkan adanya paket-paket reward yang diberikan. Salah satunya adalah guarantee compentation, yakni selain gaji pokok terdapat uang tunjangan serta diberikan uang pensiun, uang cuti, pay back cash, THR dan lain sebagainya.

\section{b. Program Pengembangan Religiositas (KeIslaman)}

Program pengemangan religiositas (KeIslaman) yang diadakan berupa Kajian Rabu Sore, Dzikir Jum'at, Do'a Pagi Bersama, Event Peringatan Hari Besar Islam (PHBI), Pengajian tematik untuk para eksekutif, Apel dan do'a bersama setiap hari senin.

\section{c. Program Pengembangan Kinerja}

Salah satu program dalam pengembangan karyawan adanya dengan adanya kenaikan jenjang karir yang lebih cepat dibandingkan dengan perusahaan lain yang sejenis. Terutama dibandingkan perusahaan perbankan konvensional yang jenjang karirnya sudah stagnant (mandeg, berhenti) sehingga dibutuhkan waktu yang sangat lama untuk karyawan agar dapat naik jabatan.

\section{d. Training dan Pelatihan Karyawan}

Training dan pelatihan karyawan terdiri dari Basic Training untuk Karyawan Baru Fresh Graudate dan Training dan Pelatihan untuk Karyawan Baru Special Hiring 
96 | Nuroniah \& Triyanto: Analisis Pengaruh Tingkat Religiositas terhadap Kinerja Karyawan Bank syariah...

\section{Tingkat Religiositas Karyawan}

Dari hasil penelitian (kuesioner) ditemukan bahwa 52\% atau 56 orang responden berada pada posisi sangat religius. 38\% atau 40 orang berada pada posisi religius, sedangkan $10 \%$ atau 11 orang sisanya berada posisi cukup religius. Sehingga dapat disimpulkan bahwa sebagian besar karyawan bank syariah $\mathrm{x}$ berada pada posisi sangat religius.

Salah satu faktor pendukung utamanya adalah bahwa hal ini sesuai dengan upaya yang dilakukan perusahaan dalam meningkatkan dan mengembangkan religiositas karyawan. Dengan adanya program-program religiositas rutin, seperti doa pagi, pengajian rabu sore, dzikir jum'at dan sebagainya. serta ditunjang dengan budaya kerja para karyawan yang selalu berusaha untuk melakukan sholat dhuha setelah atau sebelum do'a pagi.

Hasil penelitian ini menunjukkan bahwa tingkat religiositas karyawan adalah tergolong relatif sangat religius. Hal ini terutama didukung oleh adanya budaya dan lingkungan perusahaan yang relatif sangat Islami. Sehingga hal ini kemungkinan besar akan berpengaruh terhadap karakter dan perilaku para karyawan. Pada akhirnya akan dapat terefleksikan kedalam hasil pekerjaan atau kinerja.

\section{Tingkat Kinerja Karyawan}

Hasil penilaian kinerja periode tahun 2011 oleh HCD menunjukkan bahwa sebagaian besar kinerja karyawan bank syariah x yaitu relatif sangat baik. Hal ini terlihat dari banyaknya karyawan yang termasuk dalam peringkat Baik (+), Lebih Baik dan Sangat Baik. Kinerja karyawan yang relatif sangat baik mencapai angka $90 \%$ dari total 2020 karyawan kantor pusat bank syariah $\mathrm{x}$.

Sedangkan hasil penelitian ini menemukan bahwa 76\% karyawaan berada pada posisi baik dan sangat baik. Sedangkan $24 \%$ sisanya berada pada posisi kinerja cukup baik. Hal ini menunjukkan bahwa kinerja karyawan yang relatif sangat tinggi akan memberikan keuntungan yang tinggi pula bagi perusahaan. Kinerjayang realtif tinggi inisalah satu kemungkinannya adalah dipengaruhi oleh tingkat religiositas para karyawan. Sehingga visi dan tujuan perusahaan akan dapat tercapai. Kemudian pencapaian ini akan semakin dipercepat seiring dengan peningkatan kinerja para karyawan. Dari data penilaian kinerja oleh HCD dan peneliti dapat disimpulkan bahwa kinerja karyawan bank syariah tergolong relatif sangat baik.

\section{Pengaruh Tingkat Religiositas terhadap Kinerja Karyawan}

Tingkat religiositas karyawan bank syariah $\mathrm{x}$ relatif sangat religius. Hal ini tidak berarti bahwa religiositas sangat berpengaruh (menjadi faktor utama) akan tingginya kinerja karyawan. Kinerja yang relatif sangat baik ini diperoleh karena terdapat faktorfaktor lain, selain tingkat religiositas, yang lebih dominan berpengaruh. Seperti motivasi kerja, kepuasan kerja, dan sebagainya. Akan tetapi kegiatan pengembangan religiositas ini masih tetap dibutuhkan. Karena hal tersebut merupakan asset yang sangat berharga bagi perusahaan untuk jangka panjang. Sehingga kualitas SDM akan terus meningkat seiring peningkatan pengembangan (terutama religiositas) para karyawannya. 
Jurnal Ekonomi dan Perbankan Syariah

Vol. 3. No.1, April 2015: 85-98, ISSN (cet): 2355-1755

\section{SIMPULAN}

kesimpulan penelitian sebagai berikut:

a. Berdasarkan analisis kuantitatif dan kualitatif dapat disimpulkan bahwa tingkat religiositas karyawan bank syariah $\mathrm{x}$ tergolong relatif sangatreligius.

b. Berdasarkan analisis kuantitatif dan kualitatif disimpulkan bahwa kinerja karyawan bank syariah x masuk dalam kategori relati sangat baik.

c. Berdasarkan analisis kuantitatif dan kualitatif ditemukan bahwa tingkat religiositas mampu mempengaruhi kinerja karyawan secara cukup signifikan.

Untuk penelitian selanjutnya peneliti menyarankan untuk menggunakan objek lain. Baik sesama lembaga perbankan mauupun perusahaan atau lembaga atau organisasi lainnya, baik yang konvensional maupun syariah. Untuk penelitian selanjutnya, peneliti menyarankan apabila ingin meneliti tentang religiositas, mencoba mencari dan menggunakan teori religiositas yang lebih sempurna yang diambil dari Al-Qur'an, Sunnah, serta sumber-sumber Islam lainnya. Kemudian bandingkan dengan teori yang digunakan pada penelitian ini. sehingga penelitian tentang religiositas akan terus berkembang. Dari hasil penelitian ini, setidaknya mampu memberikan gambaran mengenai tingkat religiositas dan kinerja karyawan bank syariah $\mathrm{x}$. Sehingga pihak perusahaan bisa terus mengembangkan dan meningkatkan kinerja karyawan, salah satunya dengan cara meningkatkan religiositasnya. Bagi karyawan yang berlatar belakang pendidikan nonsyariah, harus ada pengajaran-pengajaran tentang nilai-nilai filosofi bank syariah secara khusus. Agar pemahamannya tidak setengah-setengah, atau malah tidak paham sama sekali mengenai nilai syariah itu sendiri. Sedangkan tugas dari karyawan yang berlatar belakang syariah, adalah sudah sepantasnya karyawan tersebut mampu mentransformasi dan menyalurkan nilai-nilai syariah yang telah dipelajari kepada karyawan lain yang berlatarbelakang non-syariah. Sehingga pemahaman tentang filosofi dasar bank syariah tersebut dapat dipahami dan diamalkan oleh semua karyawan.

\section{DAFTAR PUSTAKA}

Al-Jauziyah, I. Q. (1998). Madarijus Salikin (Pendakian Menuju Allah). Jakarta: Pustaka AlKautsar.

Al-Jazairi, A. B. (2000). Ensiklopedi Muslim (Minhajul Muslim). Jakarta Timur: Darul Falah. Al-Qalami, A. F., \& Al-Banjari, A. W. (2004). Riyadus Shalihin (Terj.). Gitamedia Press.

Ancok, D., \& Suroso, F. N. (1995). Psikologi Islami. Yogyakarta: Pustaka Pelajar.

Ash-Shabuni, S. M. (2007). Indahnya Cahaya Al-Qur'an Ali 'Imran (Keluarga Imran). Bandung: Media Hidayah Publisher.

Ash-Shabuni, S. M. (2005). Indahnya Kerlip Cahaya Al-Qur'an. Bandung: Media Hidayah Publisher.

Asnaini. (2008). Pengembangan SDM Perbankan Syariah. Indonesia: Jurnal Ekonomi Islam La_Riba vol. II No.1.

Azmi, R. (2010). Hubungan Antara Religiositas dengan Komitmen Pada Organisasi Pegawai PT. Elnusa Divisi Geosains. Jakarta: Skripsi UIN. Tidak Dipublikasikan.

Badroen, F. (2006). Etika Bisnis dalam Islam. Jakarta: Kencana.

Bafadal, F. A. (2005). Pengamalan Agama di Kalangan Pemuda. Jakarta: Sekretariat Jenderal Departemen Agama RI.

Daradjat, Z. (1996). Ilmu Jiwa Agama. Jakarta: Bulan Bintang.

Dessler, G. (2008). Human Resources Management. Singapore: Pearson Prentice Hall.

Fauzi, Y. (2012). Memaknai Kerja. Jakarta: Mizan. 
98 | Nuroniah \& Triyanto: Analisis Pengaruh Tingkat Religiositas terhadap Kinerja Karyawan Bank syariah...

Gomez-Mejia, L. R. (2001). Managing Human Resources. New Jersey: Prentice-Hall, Inc.

Homisah, S. (2009). Hubungan Antara Religiositas dengan Konsep Diri Mahasiswa Psikologi UIN Syarif Hidayatulah Jakarta. Jakarta: Skripsi. Tidak dipublikasikan.

Ilyas, Y. (2002). KINERJA (Teori, Penilaian \& Penelitian). Depok: FKMUI.

Imarah, M. M. (2002). Saripati Hadits Al-Bukhari. Jakarta Timur: Pustaka Al-Kautsar.

Iqbal, M., \& Hunt, W. (2003). Ensiklopedi Ringkas Tentang Islam. Jakarta: Taramedia.

Jomier, J. (2002). Horizon Al-Qur'an. Jakarta: Bale Kajian Tafsir Al-Qur'an Pase.

Kahmad, D. (2006). Sosiologi Agama. Bandung: Remaja Rosdakarya.

Kertajaya, \& Sula, M. S. (2006). Marketing Syariah. Jakarta.

Khalafallah, D. M. (2008). Masyarakat Muslim Ideal (Tafsir Ayat-ayat Sosial). Yogyakarta: Insan Madani.

Kreitner, R., \& Kinicki, A. (2003). Perilkau Organisasi. Jakarta: Salemba Empat.

LDK, T. (2007). Materi Dasar Islam. Bogor: Al-Azhar Press.

Lukman, D. (2008). Statistik Ekonomi. Jakarta Selatan: LP UIN Jakarta.

Muthahhari, M. (2003). Pengantar Ilmu-ilmu Islam. Jakarta: Pustaka Zahra.

nn. (2012, Desember Rabu). Perbankan Syariah Dituntut Kembangkan Sektro Produktif. Republika, p. 5.

Ramayulis, \& Jalaludin. (1993). Pengantar Ilmu Jiwa Agama. Jakarta: Kalam Mulia.

Rarawahyuni, I. (2012). Pengaruh Kompensasi, Motivasi dan Kepuasan Kerja Terhadap Keinginan untuk Keluar (Turnover Intention) di Lembaga Amil Zakat. Depok: STEI SEBI. Tidak Dipublikasikan.

Rivai, e. a. (2008). Perfromance Appraisal. Jakarta: PT. Rajagrafindo Persada.

Robertson, R. (1995). Agama: dalam Analisa \& Interpretasi Sosiologi. Jakarta: PT. Raja Grafindo.

Rusdi, A. (2009). Hubungan Religiositas dengan Forgiveness Mahasiswa Sekolah Ilmu Dakwah Dirosat Islamiyah Al-Hikmah Jakart. UIN-Jakarta: Skripsi. Tidak Dipublikasikan.

Sekaran, U. (2006). Research Methods for Business Buku 1 Trans: Kwan Men Yon . Jakarta: Salemba Empat.

Sekaran, U. (2006). Researh Methods For Busniess. Buku 2. Trans:Kwan Men Yon. Jakarta: Salemba Empat.

Setiawan, A. B. (2010). Meningkatkan Nilai Kompetitif Perbankan Syariah din Indonesia. SEBI Islamic Economics \& Finance Journal , 112-123.

Sinambela, P. D. (2012). Kinerja Pegawai (Teori Pengukuran \& Implementasi). Yogyakarta: Graha Ilmu.

Stoner, J. A., Freeman, R. E., \& Gilbert, J. D. (1996). Management. Indonesia: PT. Buana Ilmu Populer.

Sugiyono. (2012). Metode Penelitiann Kuantitatif, Kualitatif dan R\&D. Bandung: ALFABETA.

Thouless, H. (1995). Pengantar Psikologi Agama. Jakarta: PT. Raja Grafindo Persada.

Timpe, A. D. (1992). Kinerja (Performance). Jakarta: Elex Media Komputindo.

Wajosumidjo. (1987). Kepemimpinan dan Motivasi. Jakarta: Ghalia Indonesia.

Winardi, J. (2004). Manajemen Perilaku Organisasi. Jakarta: Kencana. 